\title{
Genetic Variability of Chickpea (Cicer arietinum L.) Genotypes against Pratylenchus thornei and Rhizoctonia bataticola
}

\author{
Rajbabbar Jatav* and S.P. Tiwari \\ Department of Plant Pathology, JNKVV, Jabalpur (M.P.) 482004, India \\ *Corresponding author
}

Keywords

RLN, DRR, Plant height, Shoot weight and Root weight

Article Info

Accepted:

12 February 2019

Available Online:

10 March 2019

\begin{abstract}
A B S T R A C T
Root Lesion Nematode (RLN; Pratylenchus thornei Sher and Allen) is a threat to chickpea production, either alone or in presence of Rhizoctonia bataticola. The effects of inoculation of 22 chickpea genotypes with $P$. thornei alone or with joint inoculation with $R$. bataticola were investigated in a pot experiment. Culture of $P$. thornei was developed under aseptic conditions on chickpea (JG 62). The populations developed on roots were inoculated@1000 P.thornei/genotype with four treatments: Nematode alone, Nematode + DRR fungus, DRR alone and untreated. Treatments were replicated five times. Observations were recorded after 40 days of inoculation from soil and roots of each treatment. During the course of investigation, the extents of damages developed by RLN and DRR individually as well as their combinations were recorded. The study revealed, above the four times rate of reproduction due to $P$. thornei was noticed in JG 62 over the ICCV2 and JG11, suggested that JG 62 is more vulnerable to RLN as well as DRR, while the ICCV 2 and JG11 showed resistance.
\end{abstract}

\section{Introduction}

Chickpea (Cicer arientinum L.) is an important legume in India and second most important food legume throughout the world (FAOSTAT, 2012). Asia alone contributes $89.20 \%$ of the global chickpea production. The major chickpea producing countries are India (67.4\%), Australia (6.21\%), Pakistan (5.73\%), Turkey (3.86\%), Myanmar (3.74\%) and Iran (2.25) (FAOSTAT, 2013). In India, it is grown in an area of 10.22 mha with a production of $9.53 \mathrm{mt}$ and productivity 967 $\mathrm{kgha}^{-1}$ (Anon, 2013-14) where in Australia which almost doubled 1.8 t/ha (Anon, 2017). The Indian states Madhya Pradesh, Chhattisgarh, Rajasthan, Maharashtra, Uttar Pradesh, Andhra Pradesh and Karnataka together contribute $95.71 \%$ of the chickpea production and $90 \%$ of area in the country (Anon, 2013-14).

Several cause which leads to the development of disease in nature. For instance, infection by one pathogen may change the host's response to a subsequent infection by another pathogen. Many examples of interrelationship between plant parasitic nematodes and pathogenic 
fungi where one, or both species, support or increase the damage made by the other organisms have been reported earlier (Bjorsell et al., 2017; Back et al., 2002). It is essential to understand the importance of each such relationship between pathogens in order to management of diseases. Several of the various studies of interactions between $R$. solani and plant parasitic nematodes have been done under controlled conditions, such as glass house experiment (Back et al., 2010; Bhattarai et al., 2009).

Pratylenchus thornei has been identify as a major limiting factor to chickpea production in many countries viz., Syria (Greco et al., 1984), Italy (Di Vito et al., 1987), Spain (Castello et al., 1996), Turkey (Di Vito et al., 1994), North Africa (Di Vito et al., 1994), Australia (Thompson et al., 2000) and India (Walia and Seshadri, 1985) with special refences to Madhya Pradesh (Tiwari et al., 1992)

Root lesion nematodes are migratory endoparasite that causes severe yields losses to extent of significance economic damage and is to be considered as one of the most important plant parasitic nematodes affecting chickpea (Tiwari et al., 1992). Pratylenchus thornei penetrates, feed and migrate inside the root cortex and giving rise to necrotic lesion and cavities in the root, which may lead to secondary infection of the pathogen. The nematode reproduces mitotically and parthinogenitically (Fortuner, 1977) laying eggs in the cortex and completes its life cycle within the 6 weeks under the favourable conditions.

Among the chickpea diseases, DRR is the emerging as the most destructive constraints in chickpea production in India (Sharma et al., 2016). Dry root rot is caused by Rhizoctonia bataticola (Taub.) Butler [Perfect stage: Macrophomina phaseolina (Tassi) Goid]. This pathogen is soil and seed borne and recorded in more than 284 plant species throughout the world (Farr et al., 1977). In chickpea fields, the onset of disease appears as scattered drying of the plants. The tap root appears black, rotten and devoid of most of the lateral and fine roots. When the dry stem of the collar region is split vertically, minute black sclerotia are visible. Dry root rot has become a major threat to chickpea production in recent years due altered weather conditions and cohabitation either $P$. thornei, particularly on the account of longer drought spells (Sharma and Pande, 2013). The objective of the above research is to generate systemic information on the consequence of biotic stress either alone or in combination.

\section{Materials and Methods}

The experiments were conducted in pot house of Department of Plant Pathology, JNKVV, Jabalpur, India. Chickpea seed was surface disinfected with 1000 ppm sodium hypo chloride followed by three changes of sterilized water. Plants were raised in $10 \mathrm{~cm}$ earthen pots holding $500 \mathrm{~cm}^{3}$ autoclaved soils and dibbled. The experiments were arranged in a completely randomized design with four treatments (1) Nematode alone, (2) Nematode + DRR fungus, (3) DRR alone and (4) untreated control each treatments was replicated five times and each replicate consisted of a single potted plant.

\section{Plant material and inoculum}

Twenty two genotypes viz., ICCV 2, JG 62, Annigeri, ICC 4958, ICC 1882, ICC 283, ICC 8261, ICC 506-EB, Vijay, ICC 3137, IG 72953, ICC 995, ICC 5912, ICC 6263, ICC 1431, JG 11, ICCV 05530, Pb-7, ICCV 04516 , ICC 4567, ICC 15614 and ICC 1356 of chickpea, received from Principle Scientist, Center for Excellence in Genomics, ICRISAT, Hyderabad, were assessed to find out 
pathogenic behaviour of $P$. thornei and $R$. bataticola.

\section{Inoculum}

Nematodes isolated from chickpea field of BISA from cultivar $\mathrm{HCO} 5$ and process through whitehead tray extraction method (Whitehead and Hemming, 1965) on the basis of morphologically as $P$. thornei the origin of these cultures is morphologically identified axenic population. Soil and root nematode population were counted together under the stereo binocular microscope $(80 \mathrm{X})$ with the help of hand tally counter per gram root system and per $500 \mathrm{~cm}^{3}$ soil. Pure culture of $P$. thornei was developed and maintained on the susceptible chickpea cultivar JG 62 (Tiwari et al., 1992).

Rhizoctonia bataticola was isolated from infected chickpea in the field and cultured on soil gram straw medium (GSM). The GSM consisted of soil, finely pulverized gram straw and dextrose mixed in the ratio: $930 \mathrm{~g}$ soil, 50 g gram straw, $20 \mathrm{~g}$ dextrose. The media was autoclaved at $1.05 \mathrm{~kg} / \mathrm{cm}^{2}$ for 30 minutes. Autoclaved media was later inoculated with 7 $\mathrm{mm}$ disc of $R$. bataticola and incubated at 25 ${ }^{0} \mathrm{c}$ for 10 days (Bhatt, 1993).

\section{Inoculations}

For $R$. bataticola inoculations, the fungus was applied into the soil by using the soil gram straw medium (Bhatt, 1993). The inoculated GSM was mixed well with $450 \mathrm{~cm}^{3}$ of sterile soil and transferred into sterilized $10 \mathrm{~cm}$ earthen pots holding $500 \mathrm{~cm}^{3}$ soil, irrigated with $100 \mathrm{ml}$ sterilized distilled water and remained covered with clean aluminum trays for a week before sowing of the seeds.

For $P$. thornei inoculations, the nematode suspension culture was disinfected with sodium hypo chloride (1000 ppm). Each plant was inoculated with $10 \mathrm{ml}$ sterilized water holding freshly handpicked surface disinfected 1000 mature $P$. thornei females population near root by point inoculation seven days after sowing. Whereas the nematode and fungus coinoculated in Nematode + fungus experiment together into the pots after the seven days of sowing.

\section{Observations}

Observations on plant height, fresh shoot weight, fresh root weight and nematode population were recorded 40 days after inoculation of individual treatments. Nematodes were extracted from $500 \mathrm{~cm}^{3}$ soil sample according to the whitehead tray extraction method (Whitehead and Hemming, 1965) and the nematode reproduction factor was calculated from ratio of the final population / initial nematode population (Pf/Pi). A subsample of $1 \mathrm{~g}$ of soil was used from the fungus and nematode + fungus treatment for isolation of $R$. bataticola by serial dilution technique on the PDA medium.

\section{Results and Discussion}

Twenty two genotypes showed stunting and bronzing with paler green foliage holding 2 to 3 nematodes/g soil. Further, the inflorescence and pod formation were badly affected. Both nematodes and DRR infection individually and in cohabitation affected chickpea growth parameters viz., plant height, fresh root weight and fresh shoot weight.

All the genotypes evidenced significant $(\mathrm{P}=0.05)$ plant height reduction (Fig. 1) was observed except the genotypes ICC 1882 followed by ICCV 2, JG 11 and $\mathrm{Pb} 7$ whereas maximum in JG 62 over ICCV 2 in the treatment with nematode + fungus concomitant. In the nematode alone maximum plant height reduction is found in ICC 1431 followed by JG 62, ICCV 04516 and ICCV 
05530 over the JG 11, ICCV 2, ICC 1882 and ICC 283 showed the significant growth of chickpea. However JG 62 and ICC 1356 found maximum and significant plant height reduction and susceptible reaction and remaining genotypes shows the improved growth towards the fungus alone.

A significant $(\mathrm{P}=0.05)$ improved shoot weight in the presence of $R$. bataticola alone (Fig. 2) was found for all genotypes except JG 62, ICCV 04516 and ICCV 506-EB. However, in case of $P$. thornei and $R$. bataticola interaction all genotypes showed significant reduction of shoot weight except ICCV 2, JG 11, IG 72953, ICC 6263, Vijay and ICC 995. Whereas in the RLN alone expressed significant reduction in shoot weight except genotype ICCV 2, JG 11, ICC 1882, Vijay, IG 72953, ICC 6263 and ICC 995. Fresh root weight (Fig. 3) was evidenced non significant root weight reduction except JG 62, ICC 1882, ICCV 04516, ICC 4567 and ICC 1356 in presence of $R$. bataticola. Whereas all genotypes revealed significant reduction of root weight in presence of RLN and DRR except ICCV 2 and JG 11. However in nematode alone showed significant reduced root weight except the JG 11, ICC 283, ICC 4958, ICC 3137 and ICCV 2 which performed poor host to the nematode infection. In presence of RLN, maximum reproduction factor and penetration was noticed in JG 62 followed by ICC 15610 and minimum in ICCV 2 and JG 11 in the either nematode alone or concomitant with the fungus, whereas remaining genotypes found the significant increases of nematode population.

But the nematode population in the concomitant of nematode with fungus found maximum reproduction factors and damage in the concomitant due to the synergistic effect on each other and it may cause the breaking of resistance of genotypes which was previous resistant to either of pathogen but in cohabitation it was susceptible to both the pathogen.

Reproduction factor: 0 to $\mathbf{1}=$ Resistant $®$, 1.1 to $1.5=$ moderately resistant $(M R), 1.6$ to 2 = moderately susceptible (MS), above 2.1= highly susceptible (HS)

From the (Table 1) it has been evidenced that the genotypes JG 11 and ICCV 2 found resistant and less reproduction whereas ICC 283, ICC 506-EB and IG 73953 are found the moderately resistant and ICC 1882 and ICC 995 were found moderately susceptible and remaining were highly susceptible to the $P$. thornei and JG 62 was the most susceptible and prefer host to $P$. thornei for their reproduction and development in the nematode alone treatment. Whereas in the nematode were cohabitation with $R$. bataticola the genotypes JG 11 and ICCV 2 are resist the reproduction and development of the $P$. thornei as well as $R$. bataticola whereas none of genotypes were moderately resistance and remaining were found the susceptible reaction to the $P$. thornai as well as $R$. bataticola

Root Lesion Nematode and DRR are emerging constrains in the chickpea production, being soil habitat, most difficult to manage. The investigations are in accordance with the finding of Greco et al., 1984; Di Vito et al., 1987 and Tiwari et al., 1992. JG 62 favored $P$. thornei reproduction whereas ICCV 2 and JG 11 emerged as poor host. Such study is first attempt to established synergistic relationship between RLN and DRR at 22 genotypes alone and in combination.

Hence, it concluded that the Variety JG 62 is susceptible to both DRR and RLN show the significant reduction in growth and best host to RLN in individually or combined with the DRR fungus whereas, ICCV 2 and JG 11 is the resistant to RLN and DRR infection over the JG 62 (Fig. 4). 
Table.1 reactions of genotypes against $P$. thornei reproduction factor in $P$. thornei alone or concomitant with $R$. bataticola

\begin{tabular}{|c|c|c|c|c|}
\hline \multirow{2}{*}{ Genotypes } & \multicolumn{2}{|c|}{ Nematode alone } & \multicolumn{2}{|c|}{$\mathrm{N}+\mathrm{F}$ co-inoculation } \\
\hline & Reproduction Factor & Reaction & Reproduction Factor & Reaction \\
\hline Annigeri & 2.26 & HS & 3.62 & HS \\
\hline ICC4958 & 2.35 & HS & 2.97 & HS \\
\hline ICC1882 & 1.73 & MS & 2.05 & MS \\
\hline ICC283 & 1.36 & MR & 1.84 & MS \\
\hline ICC8261 & 2.66 & HS & 2.98 & HS \\
\hline ICC506-EB & 1.38 & MR & 2.21 & HS \\
\hline Vijay & 3.00 & HS & 3.91 & HS \\
\hline ICC3137 & 2.26 & HS & 3.62 & HS \\
\hline IG72953 & 1.40 & MR & 2.98 & HS \\
\hline ICC995 & 1.87 & MS & 3.22 & HS \\
\hline ICC5912 & 2.69 & HS & 3.61 & HS \\
\hline ICC6263 & 2.64 & HS & 2.71 & HS \\
\hline ICC1431 & 3.19 & HS & 4.07 & HS \\
\hline JG11 & 0.46 & $\mathrm{R}$ & 0.96 & $\mathrm{R}$ \\
\hline $\mathrm{Pb} 7$ & 2.55 & HS & 3.99 & HS \\
\hline ICCV04516 & 3.08 & HS & 4.15 & HS \\
\hline ICC4567 & 3.32 & HS & 4.45 & HS \\
\hline ICC15614 & 3.45 & HS & 4.91 & HS \\
\hline JG62 & 4.54 & HS & 6.25 & HS \\
\hline ICCV2 & 0.37 & $\mathrm{R}$ & 0.45 & $\mathrm{R}$ \\
\hline ICCV05530 & 3.12 & HS & 4.21 & HS \\
\hline ICC 1356 & 2.91 & HS & 4.54 & HS \\
\hline
\end{tabular}

Reproduction factor: 0 to $1=$ Resistant ${ }^{\circledR}, 1.1$ to $1.5=$ moderately resistant (MR), 1.6 to $2=$ moderately susceptible (MS), above $2.1=$ highly susceptible (HS)

Fig.1 Per cent plant height reduction of genotypes against nematode and fungi

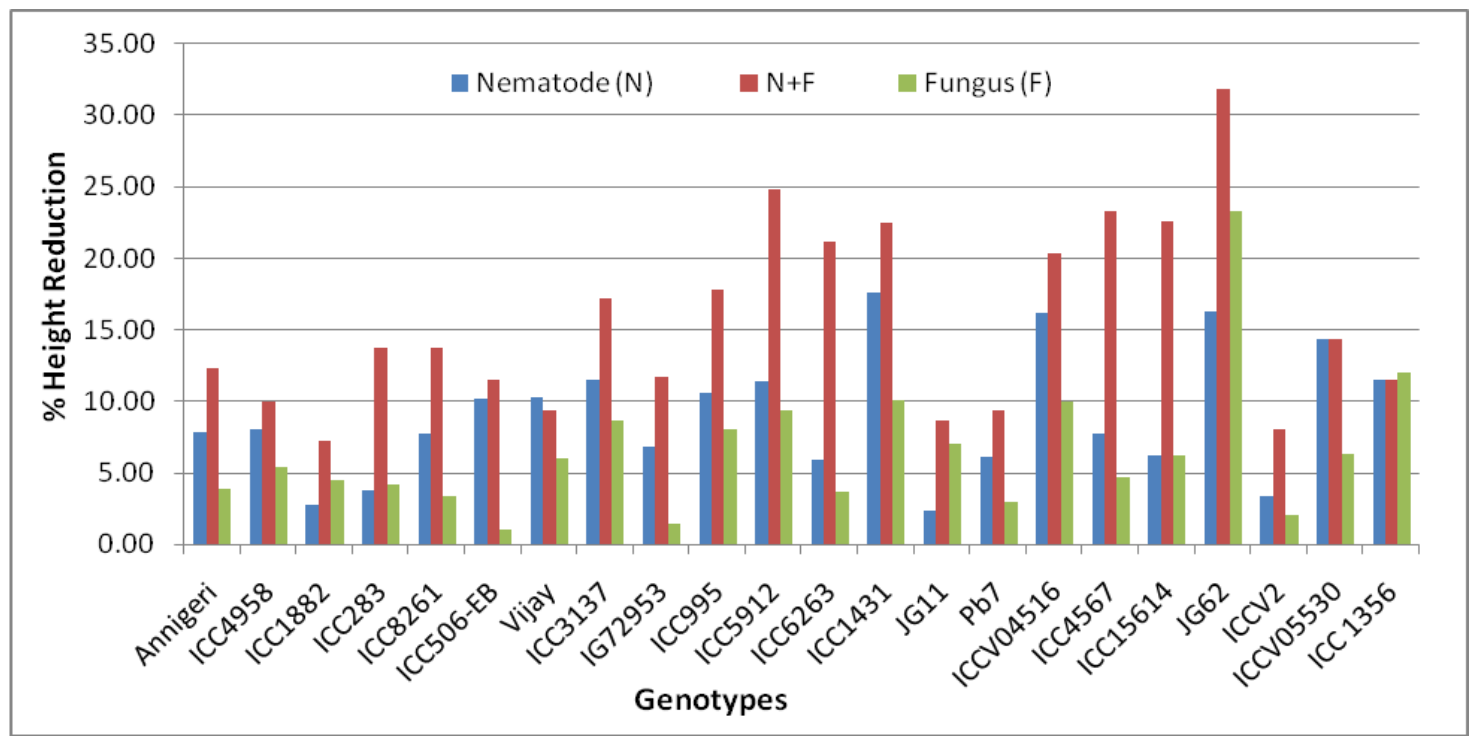

The observations were significant at $(\mathrm{P}=0.05)$ degree of significance 
Fig.2 Per cent reduction of shoot growth in presence of nematode and fungus

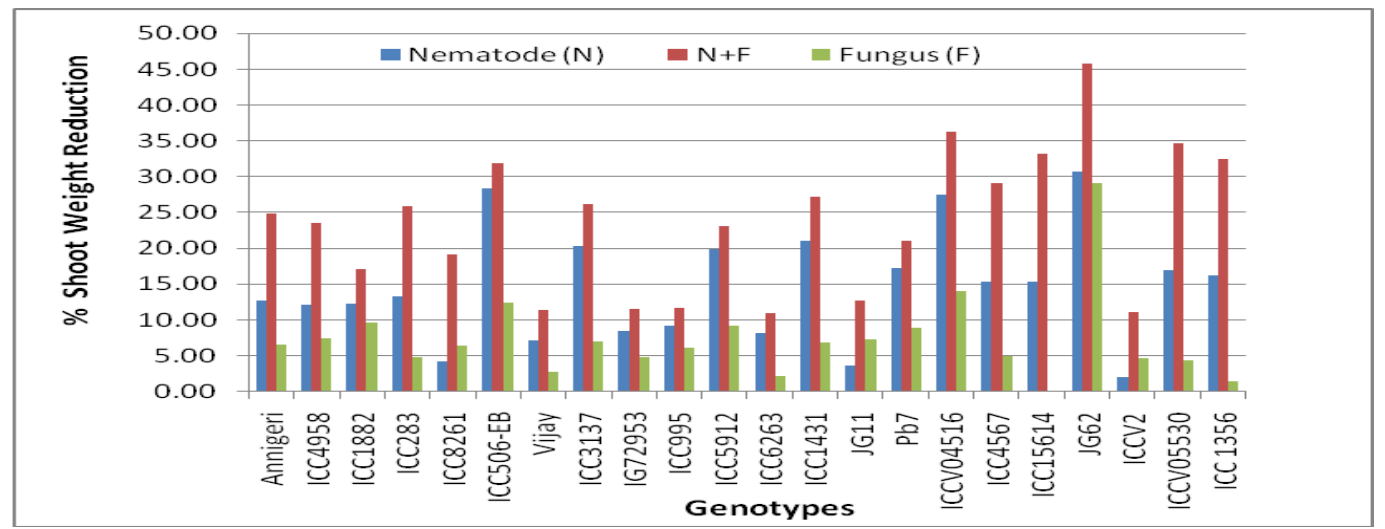

Fig.3 Effect of nematode and fungus on root weight over the genotypes

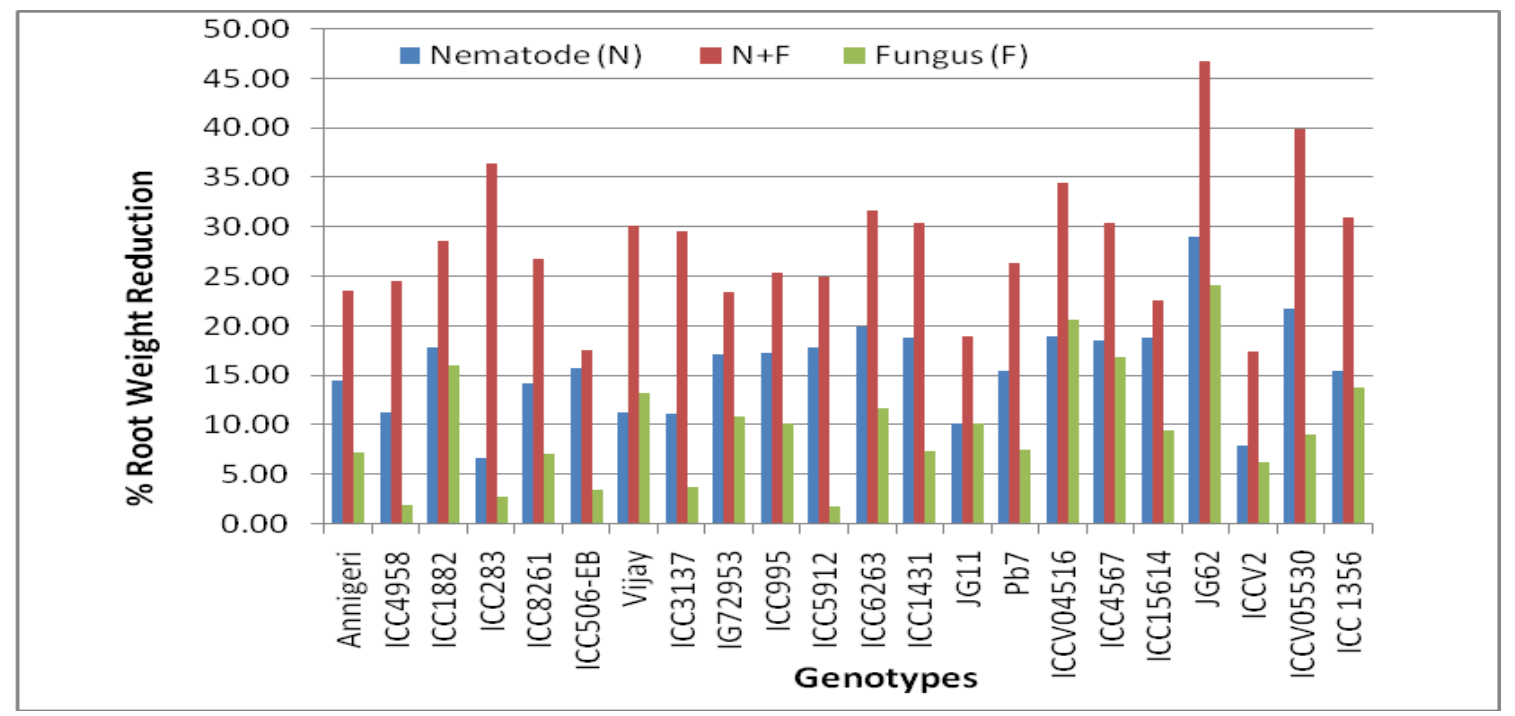

Fig.4 Reproduction factor of nematode development in roots of genotypes

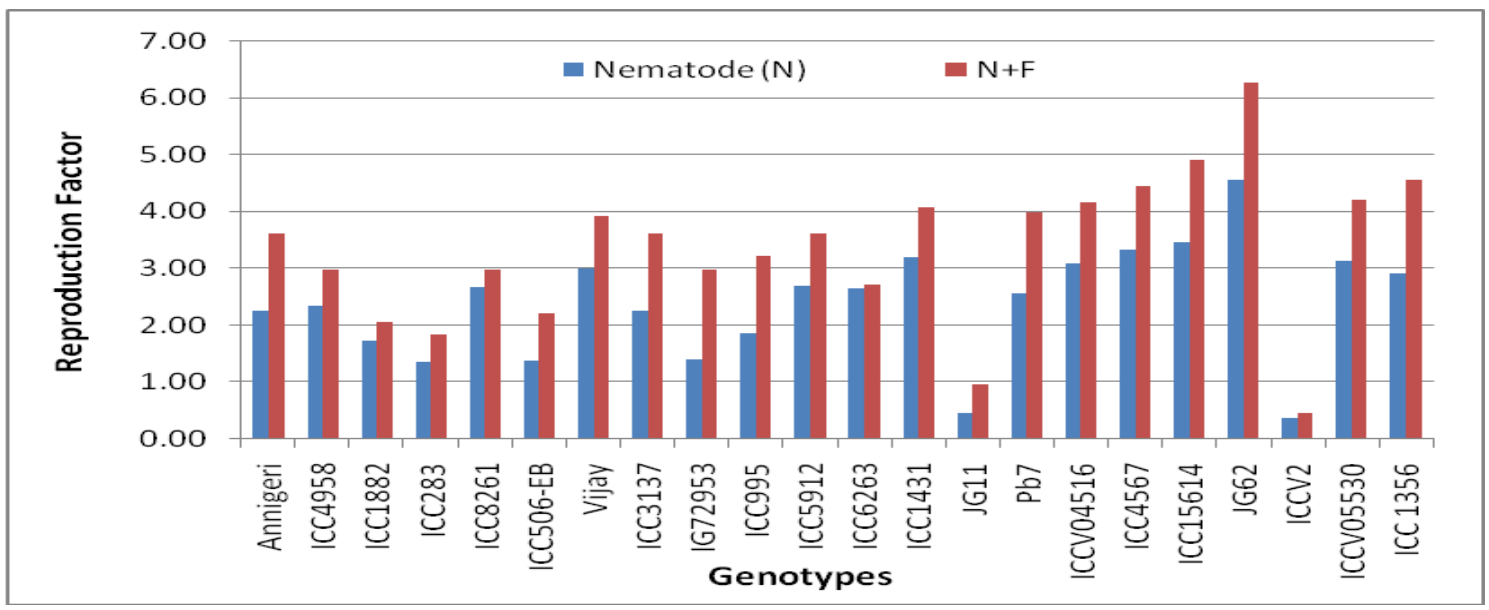


The reproduction factors of $P$. thornei was higher in the cohabitation treatment with the $R$. bataticola as compare with the nematode alone because the both pathogens showed the synergistic reaction towards the each other and which leads to the increased the severity of disease as the same results are found by the Taheri et al (1994). The genotypes which may resistant to either of the pathogen in alone whenever the disease complex of these pathogen which leads to break the resistant and make it favourable to attack and damages of host plants.

\section{Acknowledgement}

I wish to thank, M. Thudi, (Senior Scientist) ICRISAT, Hyderabad, who providing seeds and laboratory for my work.

\section{References}

Anon (2013-14) Ministry of agriculture, government of India. http://agricoop.nic.in

Anon (2017) http://agriculture.govt.au/ researchtopics/agriculturalcommodities/ agricultural-commodities-trad-data\# 2017

Back M, Haydock P and Jenkinson P (2002) Disease complexes involving plant parasitic nematodes and soil borne pathogens. Plant pathology 51: 683-697

Back M, Jenkinson P, Deliopoulos $\mathrm{T}$ and Haydock P (2010) Modification in the patato rhizosphere during infestations of Globodera rostochienses and subsequent effects on growth of Rhizoctonia solani. Eur. J. Plant Pathol. 51: 459-471

Bhatt J (1993) Reaction of chickpea cultivars to Rhizoctonia bataticola (Taub.) Butler. Indian Journal of Pulses Research 6: 118-119.

Bhattarai S, Haydock PPJ, Back MA, Hare MC and Lankford WT (2009)
Interactions between the potato cyst nematodes, Globodera pallid, $G$. rostochiensis and soil borne fungus Rhizoctonia bataticola (AG3), disease of potatoes in the glasshouse and fields. Nematology 11: 631-640

Bjorsell P, Edin E and Viketoft M (2017) Interactions between some plant parasitic nematodes and Rhizoctonia solani in potato fields. Applied Soil Ecology 113: 151-154.

Di Vito M, Greco MN and Zeccheo G (1987) Nematode problems in cultivation of chickpea. Terra Sole 534: 112-207.

FAOSTAT (2012) Food and Agriculture Organization of the United Nations, Rome. http://faostat.fao.org

FAOSTAT (2013) Food and Agriculture Organisation of the United Nations, Rome. http://faostat.fao.org

Farr DF, Bills GF, Chamuris GP and Rossman AY (1995) Fungi on plants and plant products in the United States. $2^{\text {nd }}$ edition St. Paul Minnesota, American Phytopathology Society Press.

Fortuner R (1977) Pratylenchus thornei Commonwealth Institute of Helminthology descriptions of plant parasitic nematodes. Set 7, No. 93, Commonwealth Agricultural Bureaux: Famham Rayal, UK

Greco N, Di Vito M, Reddi MV and Saxena MC (1984) A preliminary report of survey of plant parasitic nematodes of leguminous crops in Syria. Nematologia Mediterrania 12: 87-103

Loof PAA (1991) The family Pratylenchidae, 1949, pp 363-421 in manual of agricultural nematology, W.R. Nickle, ed. Marcel Dekker, Inc., New York.

Nene YL, Sheila VK and Sharma SB (1996) A world list of chickpea and pigeonpea pathogens. Fifth edition, International crops Research Institute for the SemiArid Tropics (ICRISAT), Patancheru, 
Telangana, India

Pande S and Sharma (2010) Climate change; potential impact on chickpea and pigeonpea diseases in the rainfed semi arid tropics. In; international food legumes research conference (IFLRC V) and $7^{\text {th }}$ European conference on grain legumes (AEP VII) 26-30 April 2010 Antalya, Turkey

Sharma M, Ghos Rand Pande S (2016) Dry root rot [Rhizoctonia bataticola (Taub.) Butler]: an emerging disease of chickpea- where do we stand? Archives of Phytopathology and Plant Protection 48: 13-16, 797-812

Sharma S and Sharma M (2013) Unraveling effects of temperature and soil moisture stress response on development of dry root rot [Rhizoctonia bataticola (Taub.)
Butler] in chickpea. Journal of Plant Science 4: 584-589.

Tiwari SP, Vadhera I, Shukla BN and Bhatt J (1992) Studies on the pathogenicity and relative reactions of chickpea lines to Pratylenchus thornai (Filipjev, 1936) Sher and Allen, 1953. Indian Journal of Mycology and Plant Pathology 22(3): 255-259

Walia RK and Seshadri AR (1985) Pathogenicity of the root lesion nematode Pratylenchus thornei on chickpea. International Chickpea Newsletter 12: 31

Whitehead AG and Hemming JR (1965) A comparison of some quantitative methods of extracting small vermiform nematodes from soil. Annals of Applied Biology 55: 25-38

\section{How to cite this article:}

Rajbabbar Jatav and Tiwari, S.P. 2019. Genetic Variability of Chickpea (Cicer arietinum L.) Genotypes against Pratylenchus thornei and Rhizoctonia bataticola. Int.J.Curr.Microbiol.App.Sci. 8(03): 1625-1632. doi: https://doi.org/10.20546/ijcmas.2019.803.189 